\title{
KTN1 Gene
}

National Cancer Institute

\section{Source}

National Cancer Institute. KTN1 Gene. NCI Thesaurus. Code C97601.

This gene plays a role in kinesin function. 